\title{
1 Factors Influencing Residential Water Consumption in Wallonia, Belgium
}

2 Nguyen Bich-Ngoc ${ }^{\mathrm{a},}$,, Cédric Prevedello ${ }^{\mathrm{b}}$, Mario Cools $^{\mathrm{a}}$, Jacques Teller $^{\mathrm{a}}$

3 a LEMA, Urban and Environmental Engineering Department, University of Liège

$4 \quad$ b Aquawal SA

$5 \quad{ }^{*}$ Corresponding author, email address: bichngoc.nguyen@uliege.be

6

7 The published version is available at https://doi.org/10.1016/j.jup.2021.101281

\section{Abstract}

9 Studies on residential water determinants often considered a limited number of possible factors 10 due to lacking data, especially at micro-levels. This study aims to address the simultaneous 11 effects of (1) household characteristics, (2) alternative sources of water, (3) dwelling properties,

12 (4) water appliances, (5) attitudes, and (6) urban form on household water use in Wallonia

13 (Belgium). Results emphasize the importance of household characteristics, use of alternative 14 water sources, and dwelling properties. When compared to these variables, the influence of 15 urban density appears very limited. Accordingly, the often-observed location factors are mainly 16 related to the shared household characteristics, such as composition, income, lot area, or the 17 practice of using rainwater.

18 Keywords: residential water demand; households; spatial variability

191 Introduction

20 Measuring and, more importantly, accurately forecasting demand have become essential than 21 ever for water utilities and city planners to ensure financial, ecological, and social 22 sustainability. Even in temperate regions such as Wallonia (Belgium), where water shortage is 23 often not a problem, understanding the trends and drivers in water use is still crucial. Since 
1996, despite the rise in both the numbers of connections and population, the total potable water sold in various municipalities in Wallonia has declined continually, with an average rate of - 0.9\% a year (Westhoff and Dewals, 2015). Efficient water use technologies, active conservation programs, and changes in people's perceptions and behavior are among the commonly identified drivers behind this phenomenon (Franczyk and Chang, 2009). Besides the undisputable conservation benefit, water utilities' revenue is declining due to this trend, while infrastructure repair and replacement costs still must be met (Beecher and Chesnutt, 2012). Meeting the cost while still encouraging conservation efforts and maintaining water accessibility for everyone is a conundrum question for both utilities and policymakers. Hence, accurate water demand prediction based on location- or country-specific knowledge of water use determinants would be the first step in solving this question (Bich-Ngoc and Teller, 2018). In recent years, the literature on water demand has included several potential factors such as economic, sociodemographic, physical properties, technological, climatic, and spatial drivers (Bich-Ngoc and Teller, 2018; House-Peters and Chang, 2011). All these determinants produce a very complex picture with many possible interrelationships and feedback loops. Lack of data, especially at the household level, is often the main challenge for researchers to study all these variables simultaneously (House-Peters and Chang, 2011). The choice of explanatory variables for water demand is highly subjective to forecast horizons and study locations. Seasonal variables such as rainfall and temperature often influence short-to-medium water use (Maidment et al., 1985; Wong et al., 2010). However, socio-economic factors, climate, and land-use changes show significant power in predicting long-term demand (Donkor et al., 2014; Polebitski et al., 2011).

Another factor influencing water use that has recently gained more and more attention in the

47 literature is the spatial effect (Bich-Ngoc and Teller, 2018). Wentz and Gober (2007) suggested that households tend to consume water at a comparable level to their neighbors, irrespective of 
49 their demographic and economic characteristics. Additionally, using the metropolitan area of

50 Barcelona as a case study, March and Saurí (2010) linked regions having high net population

51 density with lower average water consumption; while Kulinkina et al. (2016) found a positive

52 association between distances $(\mathrm{m})$ to the nearest alternative water source and piped water

53 consumption in their study in Ghana. Despite the increasing number of papers including spatial

54 variables as an explanatory factor for residential water demand, these studies often employed data at aggregated spatial levels such as multi-family residential buildings (Kontokosta and Jain, 2015), census tracts (Polebitski and Palmer, 2010), and counties (Franczyk and Chang, 2009). This common practice innately neglects the spatial variability resulting from natural and social processes among individual users. Hence, random- and mixed-effects models have been considered in several studies to analyze both the within variations of water use among households in the same spatial entity and the between spatial units variations (Duerr et al., 2018; Mini et al., 2015). While better capturing the household-level variation, only a limited number of covariates were included in these studies due to the lack of data at the same detail

63 level.

64 By combining actual water consumption with questionnaire data containing potential explanatory factors at the household level of more than 2,000 households in Wallonia, this study aims to answer the following research questions: (1) What are the determinants of residential water consumption in Wallonia? (2) Whether the spatial variation of water consumption exists beyond these predictors? Furthermore, if yes, (3) what are the possible explanations for spatial variability in water use in Wallonia? 


\subsection{Data collection and processing}

\subsubsection{Study region}

Wallonia is the predominantly French-speaking region of Belgium, which comprises $55 \%$ of Belgium's physical territory and around $32 \%$ of its population. The Walloon population mainly concentrates in the northern areas following the $19^{\text {th }}$-century industrial axis, running from east (Liege) to west (Mons). Administratively, the region consists of 20 administrative arrondissements dividing into 262 municipalities. Wallonia, as well as Belgium as a whole, has an oceanic temperate climate that generally features mild summers and cool winters. Although Wallonia has a typically reliable and constant precipitation level throughout the entire year, together with a large part of Europe, the region recently experienced anomalous droughts in the summers of 2018 and 2019 (Buras et al., 2020).

The region has been the water reservoir of Belgium, with a long history of water export to the Brussels-Capital and Flemish regions. Even though aquifer accounts for $75 \%$ to $84 \%$ of total distribution water, the water exploitation index plus (WEI+) of Wallonia is often less than $8 \%$, i.e., water is not scarce in Wallonia (European Environment Agency, 2019). Water production and distribution in Wallonia are provided entirely by public companies brought together by the Professional Union of Public Water Cycle Operators (Aquawal). The average water consumption in Wallonia reported for 2016 was 118.6 L per inhabitant per day. However, when only residential use was considered, the average consumption was estimated at around $90 \mathrm{~L}$ per inhabitant per day (Aquawal, 2017). With this level of consumption, Wallonia is among the regions with the lowest residential water consumption in Europe (EurEau, 2017). Similar to most places in the developed world, Wallonia is currently experiencing a constant decline in water consumption, which can be up to $2 \%$ per year in some municipalities, in both terms of total and per capita consumptions (Vallès-Casas et al., 2017; Westhoff and Dewals, 2015). 
95 Following the European principles of full-cost recovery, a single water tariff structure

96 (Appendix A), which covers the cost of both water production and sanitation, is imposed for

97 all Wallonia families. Despite a recent rise in water tariff, in 2014, the annual water cost for a

98 family in Wallonia is averaged at about EUR 380, which is around the median of European

99 countries and, in most cases, accounts for less than $3 \%$ of household disposable income

100 (Aquawal and CEHD, 2015; EurEau, 2017).

\subsubsection{Utility survey}

102 Predictors of water consumption at the household level employed in this study were obtained

103 from the Water and Energy Utilization Survey data in the Household and Cost 2015 (Utility

104 Survey in short). It was carried out by Aquawal (The Union of Public Water Cycle Operators) and CEHD (Centre d'Etudes en Habitat Durable de Wallonie) in two waves in early 2015. A database with meter identifications and addresses of 1.5 million households was created using

107 customer databases of all major water providers in Wallonia. In the first wave, 15,000 homes

108 were randomly selected from the database and contacted by post-mail. The contacted 109 households could complete the survey either by Paper and Pencil (with pre-stamped envelope) or Computer Assisted Web. Due to a high number of non-responses, a second wave was carried

111 out at the end of April 2015 by sending the same questionnaires to another randomly selected

11215,000 households in the region with an addition of phone survey mode. The representativeness

113 of the final 2,763 obtained responses was checked using the Walloon population's actual

114 distributions by province, reference person's age, housing tenure, and dwelling type and age.

115 Post-stratification weights were then calculated and employed in all later analyses to correct

116 for sampling bias. Doubled and uncompleted responses (abandoning before question number

117 10) were eliminated. Households who also used distribution water for professional purposes at 118 home were excluded. 
119 The Utility Survey contained a broad range of questions about water and energy consumption,

120 dwelling characteristics, household composition, water use devices, and consumption habits

121 and preferences. After removing the variables with a high proportion of missing, 48 potential

122 explanatory factors were identified and classified into five groups: (1) household

123 characteristics, (2) alternative sources of water, (3) dwelling properties, (4) water appliances, and (5) attitudes (Bich-Ngoc and Teller, 2018). Since cross-sectional data were used in this study, commonly studied variables such as price (Marzano et al., 2018), air temperature, and rainfall (Gato et al., 2007) were excluded because they have modest or no variation during the study period. A complete list of considered variables and summary statistics is included in

128 Appendix B and discussed further in 3.1.

129 Information regarding household characteristics obtained from the survey includes the number

130 of inhabitants and their ages; reported household income (nine categories); reference person's

131 gender, job, and educational level; water affordability (annual water bills as a percentage of

132 reported income); and whether the family had difficulties in paying their water bill or received

133 support from the Social Water Fund (Fonds Social de l'Eau). Since several previous studies

134 suggested that the amount of consumed water depends on the age of inhabitants (Nauges and

135 Whittington, 2009), instead of the total number of members in each household, we considered

136 the number of children ( $<14$ years old) and the number of adults $(\geq 14$ years old $)$. The number

137 of adults was recentered at the value one so that the intercepts of regression models can

138 represent the average consumption of single-member households. Additionally, coefficients

139 were used to adjust for the duration they stayed in the studied dwelling per week. As for

140 income, to better represent the buying power of the participated households, income per

141 equivalent adult was used instead of household income. This variable was calculated using the

142 mid-points of recorded household income categories and the OECD-modified equivalence 143 scales. Per capita income was then categorized as precarious-, modest-, average-, and higher- 
144 income using the cut-off values suggested by the Walloon Housing Association (Société

145 Wallonne du Lodgement) with average-income as the reference level.

146 Information regarding alternative water sources was obtained by asking the respondents to

147 indicate whether they use any alternative sources (well, rainwater, bottled water, and others)

148 for a specific purpose such as drinking or cooking, toilet flushing, garden irrigation, pool

149 filling. The survey provided a total of 48 binary variables ( 4 alternative sources $\times 12$ purposes).

150 New nominal variables were created with four levels (no use, use for indoor purposes only, use

151 for outdoor purposes only, and use for both indoor and outdoor purposes) for each type of

152 alternative water source to reduce the number of dimensions in later analyses. "No use for any

153 purposes" was chosen as the reference level for all the alternative water source variables.

154 Examples of dwelling property variables are year built, housing tenure, dwelling type, living area, number of rooms, and the presence of (a) bathtub(s), garden(s), or pool(s). The living area was scaled to have zero mean and unit variance. The presence of a garden was derived from

157 whether the households used water for irrigation purposes. Two binary variables for the 158 presence of (a) permanent pool(s) and inflatable pool(s) were considered.

159 As for water appliances, both water use appliances (washing machine, dishwasher) and water160 saving appliances (water-efficient toilet, low-flow showerhead) were considered. The 161 households were asked whether they had these appliances and whether they had recently replaced them after 2009. Hence a total of eight binary variables were included in the analysis.

163 No house visits or home water audits were carried out.

164 The survey only provided limited information regarding people's attitudes toward water use.

165 Two variables were included in this study to represent people's attitudes indirectly. The first 166 one is people's confidence in tap water quality recorded in six categories (confident, rather 167 confident, neither confident nor suspicious, rather suspicious, suspicious, and no opinion). The 
second one is whether the water bill depends on the usage volume or not because some families rent their dwellings from the private sector and pay for water through their landlords.

\subsubsection{Urban form}

171 Besides household-level determinants, the effect of urban form was addressed by population and building densities. Since most municipalities consist of a populated central urban area and low-density suburbs, both densities were calculated at the statistical-unit level, corresponding to neighborhoods in urban areas or large depopulated zones in rural areas. There are 9,876 statistical units whose areas range from 1.3 ha to 5,834 ha in Wallonia. The gross population

176 density was calculated by the total registered population per square kilometer. Building density was defined by the percentage of area covered by buildings in each statistical unit. Raw data regarding total population, total area, and cadastral maps for all statistical units were obtained from the Belgian Statistical Office ${ }^{1}$ and Federal Public Service Finance ${ }^{2}$ websites. Provided

180 addresses of participating households in the Utility Survey were used for mapping and 181 connecting with data at other spatial aggregation levels.

\subsubsection{Water consumption}

183 Our dependent variable is the water consumption $\left(\mathrm{m}^{3}\right)$ in 2014 recorded by water utilities at

184 the household level. However, different households recorded their meter at different moments

185 during the year. Hence, to standardize the data, we assumed an average daily water use during

\footnotetext{
${ }^{1}$ https://statbel.fgov.be/en/open-data?category=209

${ }^{2}$ https://finances.belgium.be/fr/particuliers/habitation/cadastre/plan-cadastral/lambert-72
} 
each recording period (e.g., March 2013 - March 2014 and March 2014 - March 2015). These

187

188

189

190

191

192

193

194

195

196

197

198

200

201

202

203

204

205

numbers will then be multiplied by the respective actual number of days belonging to 2014 to estimate the total consumption of 2014. This method was adapted from Ghavidelfar et al. (2017). Extreme value removal was based on expert advice (> $300 \mathrm{~m}^{3} /$ year) and outlier analyses (further discussed in 2.2). Water meters' identifications were used to connect the previously described survey data and recorded household water consumption in 2014.

\subsection{Multiple regression}

A vast number of possible covariates in the Utility Survey dataset increase the variable selection process's difficulty and the risk of multicollinearity due to correlation among explanatory variables. Hence, a parsimonious and well-performing linear regression model was first developed to provide a baseline for the more complex ones with spatial regressors to follow. Both categorical and continuous covariates were considered in the model $y_{k}=\boldsymbol{x}_{k}^{T} \boldsymbol{\beta}+$ $\varepsilon_{k}$, where $y_{k}$ is the total water use of household $k$ in $2014, \boldsymbol{x}_{k}$ is the vector of considered household-specific factors and their possible polynomial and interaction terms, $\boldsymbol{\beta}$ is the vector of regression coefficients, and $\varepsilon_{k}$ is the error terms. In this study, a core model including explanatory factors with a high level of consensus in the literature was first fitted (Bich-Ngoc and Teller, 2018). Partial residual plots were used to identify other important factors and their possible relation with household water consumption. Variables were only added to the model if they significantly improved the model's goodness of fit (p-value of likelihood ratio test < 0.05). Competitive models were then assessed using $k$-fold cross-validation (with $k=100$ ). Mean squared prediction errors (MSPE) from each run were averaged to produce a single estimate for each model. The final model is the model with the highest predictive power, i.e., the smallest MSPE. The potential of adding or removing several variables at once was also tested using Likelihood-ratio tests. Outliers or influential observations were identified using 
MM Estimation and several single-case diagnostics such as DFFITS, DFBETAS, and Cook's

211 distance (Ayinde et al., 2015). Variance inflation factor (VIF) and standardized residual plots

212 were used to check for violations of regression assumptions.

\subsection{Spatial variation analyses}

214 Two approaches, namely fixed effects regression with spatial predictors and mixed-effects

215 regression with spatial random intercepts, were employed to study the spatial patterns of water

216 consumption. The final baseline model resulted from the previous analysis was updated with

217 spatially varying factors such as population or building density. The model equation becomes

$218 y_{j k}=\boldsymbol{x}_{j k}^{T} \boldsymbol{\beta}+\beta_{1} d_{j}+\beta_{2} d_{j}^{2}+\varepsilon_{j k}$ with $d_{j}$ is either population density or building density of

219 statistical unit $j$, while $\beta_{1}$ and $\beta_{2}$ are respectively regression coefficients of linear and quadratic

220 terms. These models assume that the spatial pattern of water use depends on the variation in

221 densities. Additionally, random intercept at the municipality level $\left(u_{i}\right)$ was added (Verbeke and Molenberghs, 2009) to capture the effects of other possible unobserved spatially varying factors and allow different base water consumptions for different municipalities. The model

224 formula is then $Y_{i j k}=\boldsymbol{x}_{i j k}^{T} \boldsymbol{\beta}+\beta_{1} d_{i j}+\beta_{2} d_{i j}^{2}+u_{i}+\varepsilon_{i j k}$. Random effects $u_{i}$, which can also 225 be interpreted as municipality-specific deviance from the global mean of water use, is assumed 226 to follow a normal distribution $N\left(0, \sigma_{u}^{2}\right)$. This model also assumes that the effects of 227 household-specific predictors $\boldsymbol{x}_{i j k}$ on water consumption remain constant from one 228 municipality to another.

\subsection{Software}

230 All data processing and statistical modeling were performed using R-4.0.0 (R Core Team, 2020) with the aid of lme4 (Bates et al., 2015), lmerTest (Kuznetsova et al., 2017), and MuMIn packages (Barton, 2020). The scripts are available upon request from the first author. 


\section{$233 \quad 3 \quad$ Results and discussions}

\section{$234 \quad 3.1 \quad$ Data exploration}

235 On average, a household in our sample consumed around $69.4 \mathrm{~m}^{3}$ potable water in 2014 , with 236 a considerable variation among households $\left(\mathrm{SD}=44.4 \mathrm{~m}^{3}\right)$. The average daily water

237 consumption per person was $85.2 \mathrm{~L}(\mathrm{SD}=50.8 \mathrm{~L})$, close to the $90 \mathrm{~L} / \mathrm{p} / \mathrm{d}$ reported by Aquawal 238 (2017) and is modest compared to reported numbers from other European countries, as

239 discussed in 2.1. Bivariate Pearson correlations in Figure 1 suggest positive relationships 240 between household water use and household size and living area. Water consumption is also

241 negatively correlated with the reference person's age. It can be explained by the fact that, in 242 Wallonia, older people often live separately from their grown-up children and generally 243 consume less water than families with young children.

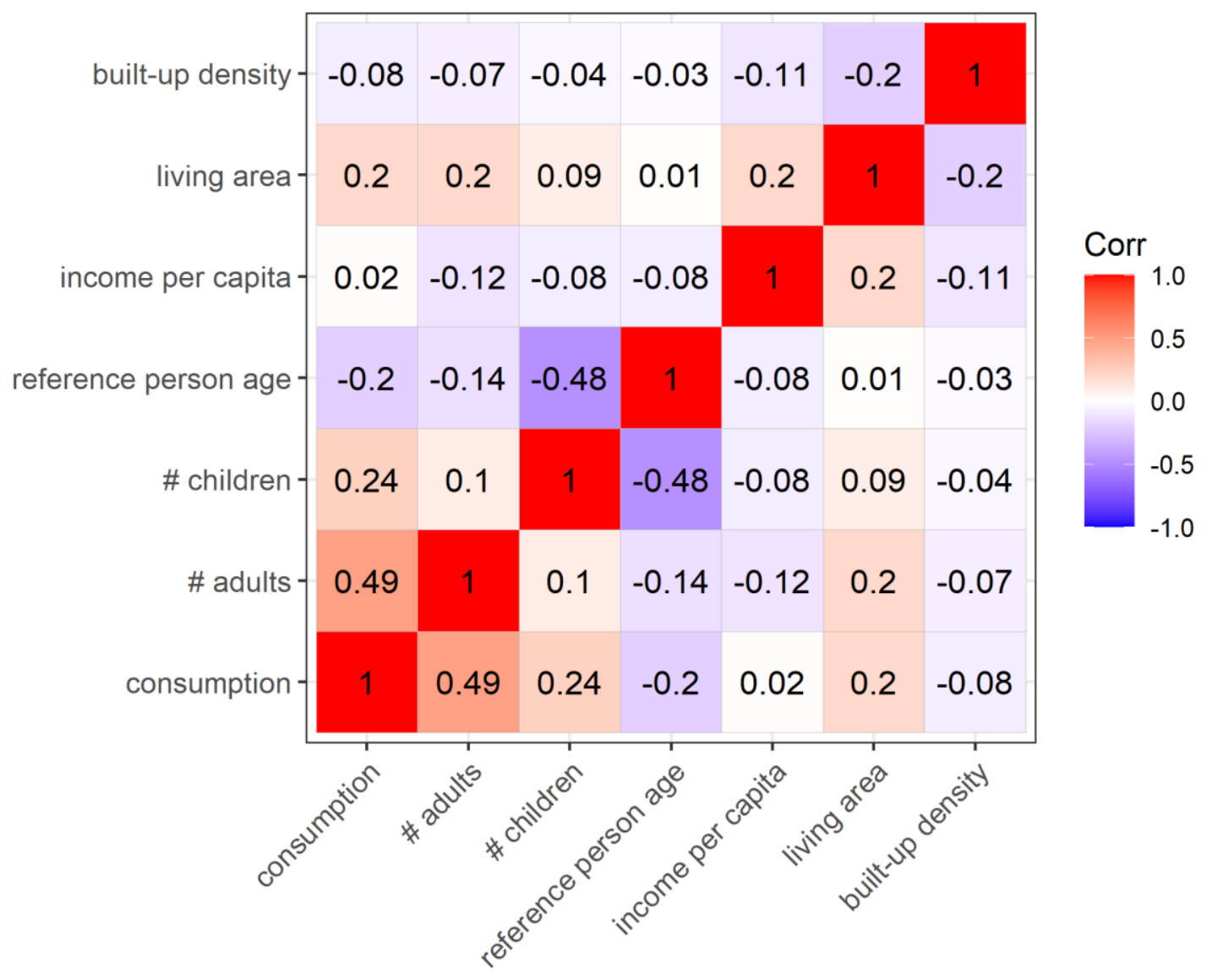


245 Figure 1. Correlation matrix of primary quantitative variables

246 Sociodemographic characteristics of the families participating in the Utility Survey were 247 somewhat comparable with the population data in 2014. The average household size in the 248 sample was 2.4, which is slightly higher than the 2.3 value of Belgium in 2014 (Anfrie et al., 249 2017). The proportion of single-member families, families with children, and couples without 250 children in the data are $23 \%, 22 \%$, and $41 \%$, respectively. Even though the average household 251 size in Belgium was relatively stable since 2010, rises in the proportions of single-member and 252 single-parent households were predicted (Anfrie et al., 2017). This trend might reduce the 253 efficiency in water use resulting from the economies of scale (Bich-Ngoc and Teller, 2018).

254 Rainwater is the primary alternative source of water in Wallonia, with about $48 \%$ of 255 respondents reported using rainwater for at least one purpose. Additionally, nearly $5 \%$ of the 256 participants answered that they used private well water. Aside from bottled one, tap water is 257 much safer than other sources of water in Wallonia. Hence other water sources such as rainfall 258 are mainly used for outdoor purposes and some specific indoor purposes such as toilet flushing 259 and cleaning (Figure 2). 


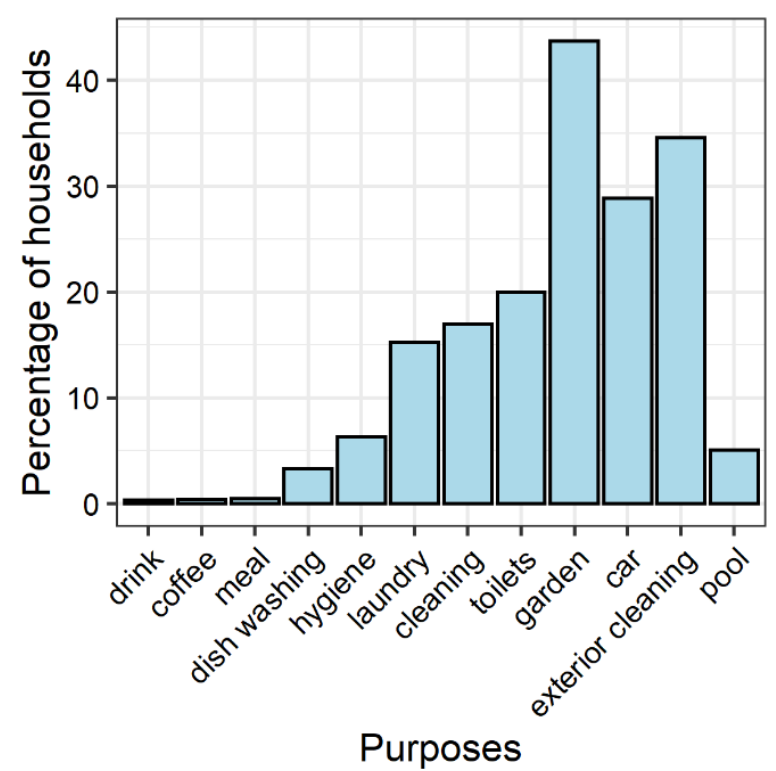

261 Figure 2. The proportion of families in the Utility Survey using rainwater for different outdoor

262 and indoor purposes

263 Generally speaking, single-family houses built before 1990 and with medium living areas made 264 up a large part of housing stock in Belgium (Anfrie et al., 2017). The average living area 265 (without considering garden and outdoor space) in the Utility Survey was $128 \mathrm{~m}^{2}$. It is positively correlated with income, though slightly (Figure 1). Although there was no recorded data regarding lot size or garden size in the dataset, nearly $80 \%$ of the families reported using distribution water for garden irrigation. While studies employing data from Australia or the US often show higher consumption during summer months due to garden irrigation and pool filling (Gato et al., 2007), the opposite seasonal pattern with lower summer consumption and higher winter water use was observed in Wallonia (Bich-Ngoc and Teller, 2020). A general cool and wet climate, moderate garden sizes, and high outbound travel activities during the summer months might be the reasons behind this (Bich-Ngoc and Teller, 2020).

274 Together with other countries in West Europe, the saturation of the water use appliances market 275 in Belgium was very high, with $92 \%$ of the families having a washing machine, and two-third of them owning a dishwasher (Pakula and Stamminger, 2010; Richter and Stamminger, 2012). 
277 Additionally, $72 \%$ of the families claimed that they had either (a) dual-flush or low-flush 278 toilet(s). Nearly $40 \%$ of the participants also reported using low-flow showerheads. Hence, the 279 variation in appliance ownership in the data was relatively modest.

280 Very few questions regarding people's attitudes and water use habits were included in the

281 Utility Survey. In general, people in Wallonia expressed high confidence in tap water quality,

282 with $78 \%$ of the respondents said they are confident or rather confident. Since water meters were fitted for all individual households in Wallonia, even in multi-family buildings, most families had direct contracts with water utilities and followed the general tariff scheme as described in Appendix A. Only $1.5 \%$ of the surveyed participants who rented their dwelling in the private sector had their water bill as a fixed amount included in their rent.

In this study, population and building densities at the statistical unit level were used as urban form indicators. Units with high overall population density or building density are often core city areas, while units with lower overall densities have a higher share of unpopulated agricultural land or forest. The summary statistics of these two variables are reported in Table 1. Both population and building densities show significant negative correlations with water 292 consumption, though slightly. The boxplots in Figure 3 also suggest slightly higher consumptions in peri-urban areas (medium built-up density) than in core city centers (high density) or rural areas (low density).

Table 1. Summary statistics of population density and building density

\begin{tabular}{|l|l|l|l|l|}
\hline Variable & Unit & Mean & SD & $\begin{array}{l}\text { Pearson's correlation with } \\
\text { water consumption }\end{array}$ \\
\hline Population density & People/km² & 2147 & 2033 & $-0.0506 *$ \\
\hline Building density & $\%$ & 11.6 & 8.75 & $-0.0758 * *$ \\
\hline
\end{tabular}

Note. $*$ and $* *$ : p-value $<0.05$ and $<0.01$ respectively 

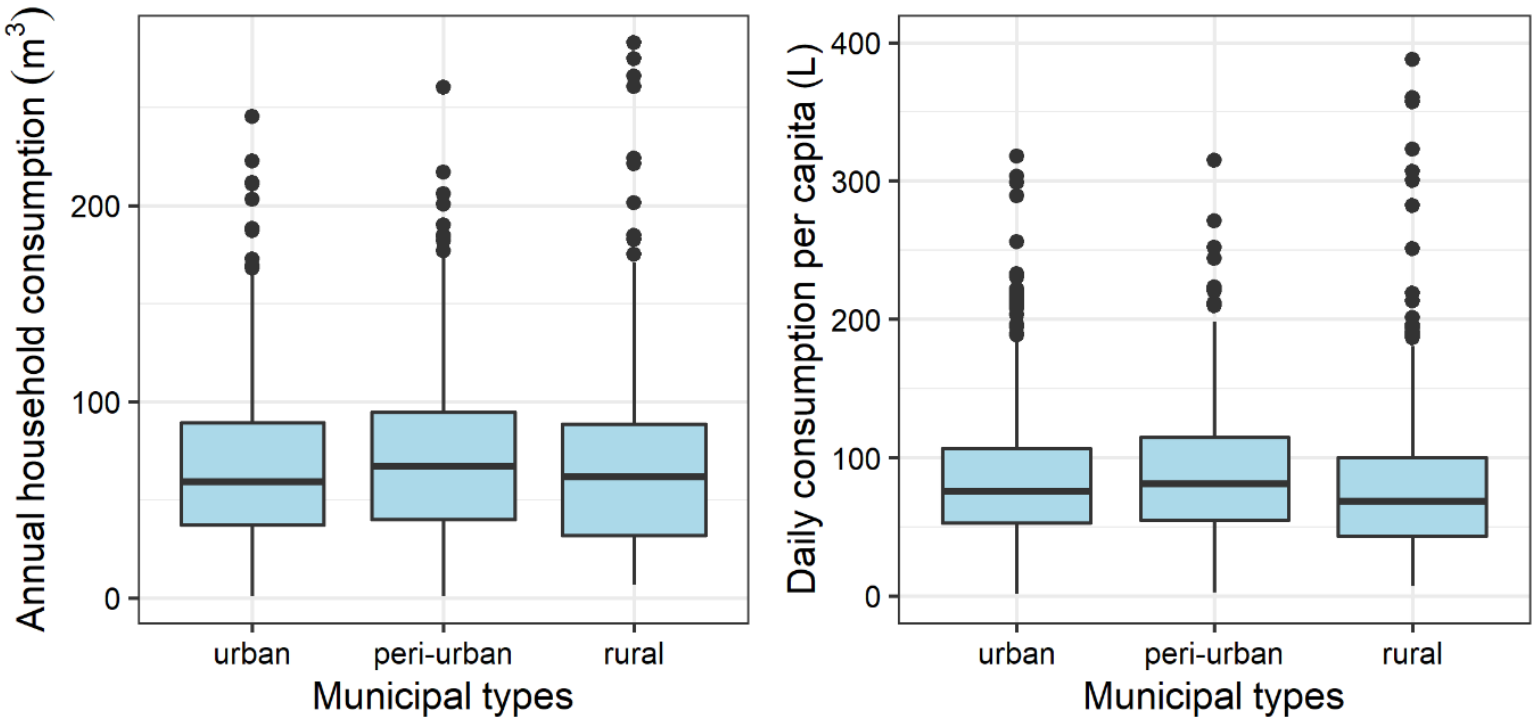

298 Figure 3. Boxplots of annual household water consumption (Left) and daily consumption per

299 capita (Right) by municipal types

300 Besides correlations with built-up density and other variations, spatial autocorrelation in water

301 consumption was also suggested by Moran's I statistic (p-value $=0.0216)$ in the data. As

302 previously mentioned, a family in the dataset consumed about $70 \mathrm{~m}^{3}$ of water in 2014 .

303 However, these average values vary among municipalities (Figure 4). Municipalities in the

304 northwest of Wallonia generally have a significantly lower average water consumption (blue-

305 colored), while a higher average of water use can be observed in the southeast area of the region

306 (red-colored). 


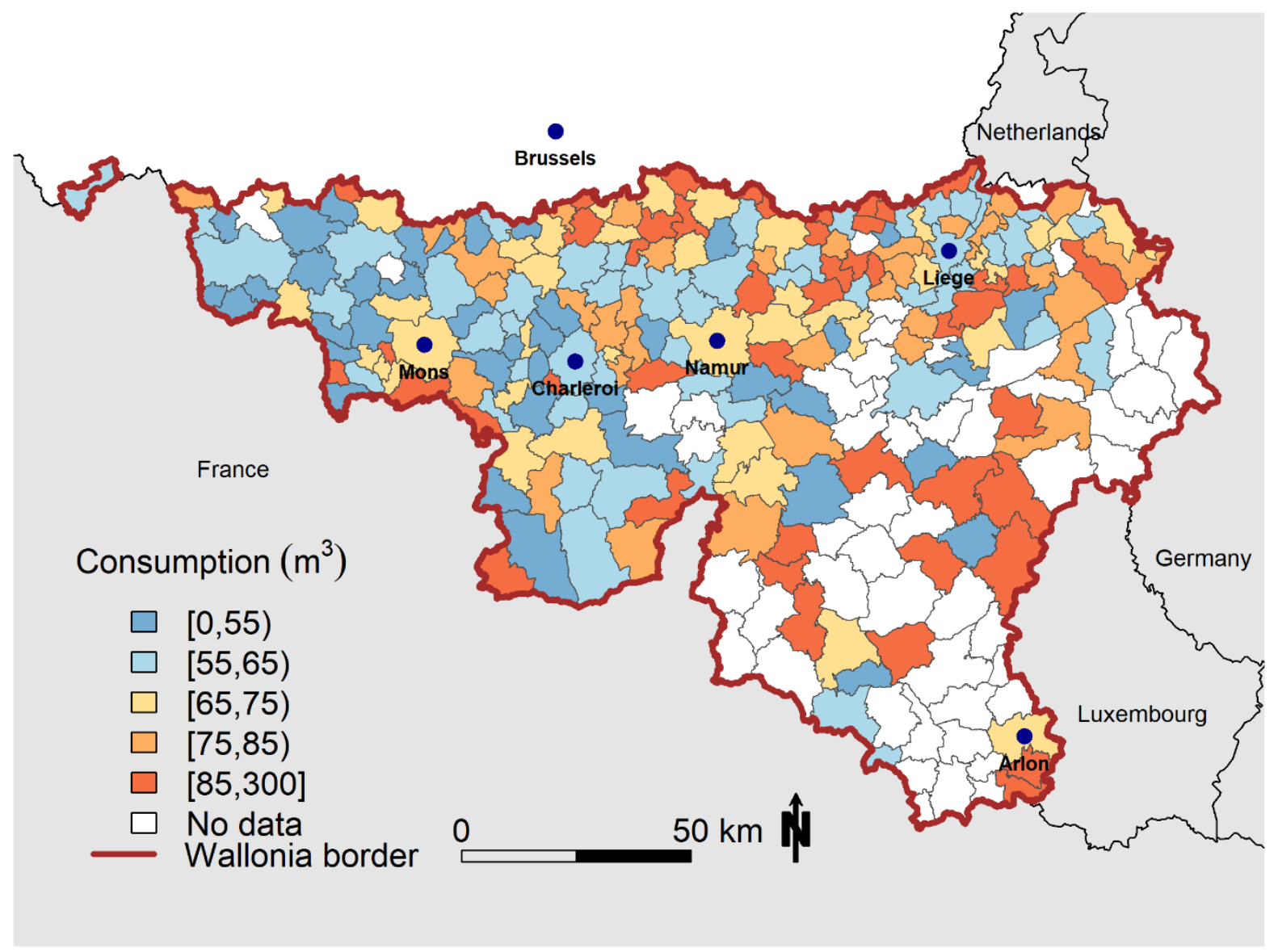

308 Figure 4. The variation of average water consumption per household in 2014 by municipalities

$309 \quad\left(\right.$ Mean $=70 \mathrm{~m}^{3} /$ household, $\mathrm{SD}=27.11 \mathrm{~m}^{3} /$ household $)$

310 Besides water consumption, several predictors in the data also express spatial variations and

311 correlations with built-up density. In Wallonia, high-density areas often have a higher share of

312 lower-income and smaller living area families (Figure 1). Additionally, significant negative

313 correlations were also observed between built-up density and the proportions of households

314 with (a) rainwater tank(s) (Pearson's $r=-0.2169$, $\mathrm{p}$-value 0.0015) and garden(s) (Pearson's $\mathrm{r}=$

$315-0.2692$, p-value $<0.001)$ at the municipality level. Results from Moran's I test also suggested

316 spatial dependencies of household income per capita ( $p$-value 0.0085 ), household size ( $p$-value

$317=0.0312)$, and the proportion of households with rainwater use (p-value $<0.001)$. 


\subsection{Multiple regression}

319 Results from the final regression models were reported in Table 2. The VIFs did not suggest

320 multicollinearity problems in the models. Additionally, linearity assumptions were checked

321 visually by partial residual plots, while homoscedasticity and normality assumptions were

322 checked using scatter and Q-Q plots of standardized residuals. Sensitivity analysis with and

323 without the outliers showed that the model estimates are stable despite different model fitting

324 or outliers identification techniques (Table 2 ). The adjusted- $\mathrm{R}^{2}$ of all final models range from

$3250.404-0.413$, belonging to the high end of the range presented in past studies that have utilized

326 household-level data. For example, the adjusted R-square in Pint's study (1999) regressing

327 water use data of 599 single-family households in California on dwelling characteristics and

328 weather is 0.25. More recent studies using household-level data, such as Basani et al. (2008)

329 and Kenney et al. (2008), obtained adjusted- $\mathrm{R}^{2}$ of 0.374 and 0.400 , respectively.

330 Table 2. Estimated effects of predictors on total household water use and their p-value using

331 different modeling methods

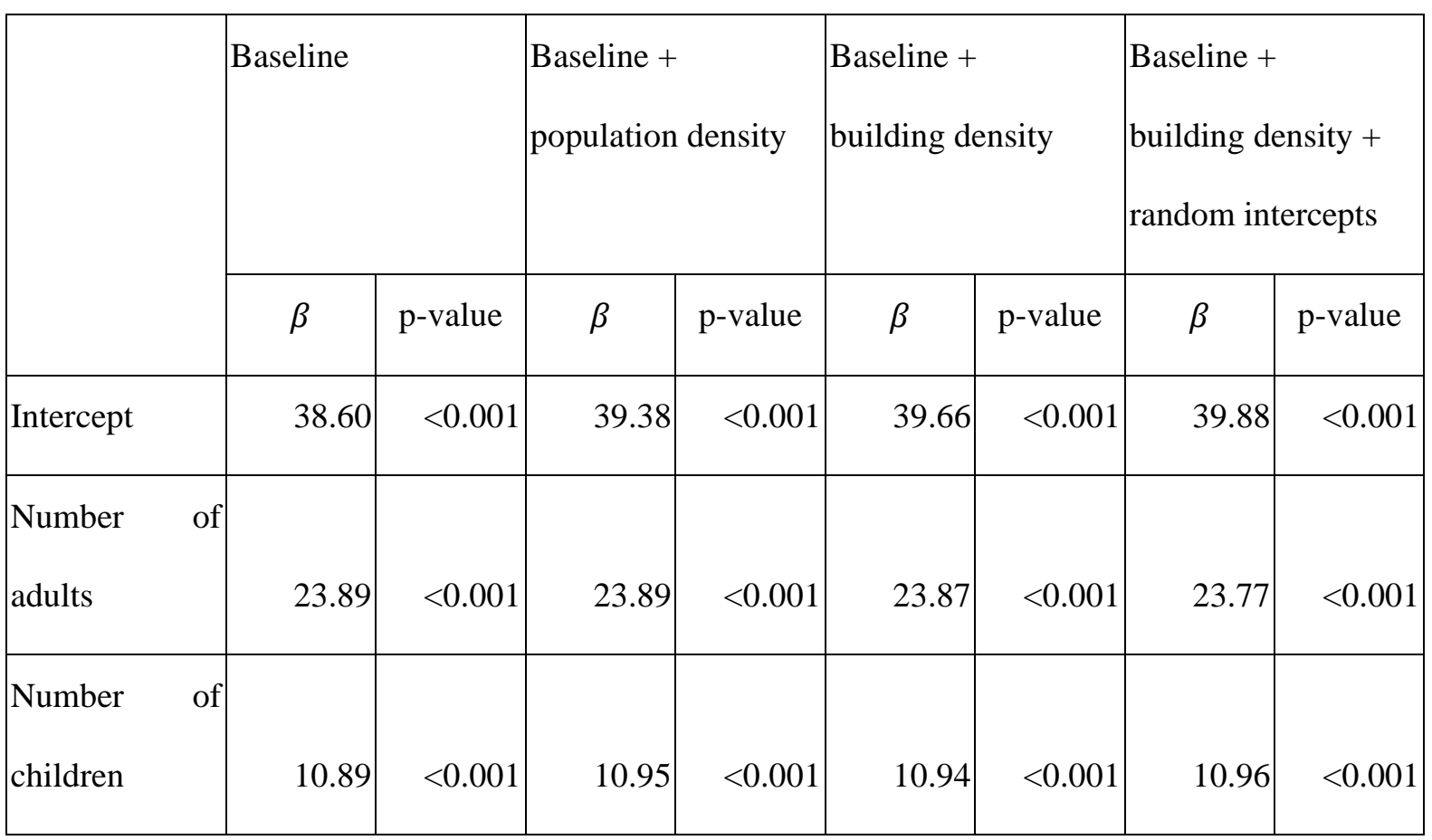




\begin{tabular}{|c|c|c|c|c|c|c|c|c|}
\hline $\begin{array}{l}\text { Income- } \\
\text { precarious }\end{array}$ & -5.15 & 0.0562 & -4.74 & 0.0792 & -4.48 & 0.0969 & -4.67 & 0.0848 \\
\hline Income- & & & & & & & & \\
\hline modest & 0.69 & 0.7333 & 0.71 & 0.7233 & 0.80 & 0.6925 & 0.81 & 0.6886 \\
\hline Income-higher & 5.55 & 0.0371 & 5.77 & 0.0303 & 5.96 & 0.0248 & 5.61 & 0.0348 \\
\hline Rainwater- & & & & & & & & \\
\hline outdoor & -3.50 & 0.1058 & -3.88 & 0.0743 & -4.07 & 0.0603 & -3.80 & 0.0804 \\
\hline Rainwater- & & & & & & & & \\
\hline indoor & -15.13 & 0.0811 & -15.39 & 0.0757 & -15.44 & 0.0744 & -14.34 & 0.0969 \\
\hline Rainwater- & & & & & & & & \\
\hline both & -25.81 & $<0.001$ & -26.40 & $<0.001$ & -26.58 & $<0.001$ & -26.48 & $<0.001$ \\
\hline Living area & 2.85 & 0.0024 & 2.62 & 0.0053 & 2.49 & 0.0080 & 2.77 & 0.0034 \\
\hline Bathtub & 5.76 & 0.0022 & 5.56 & 0.0031 & 5.59 & 0.0029 & 5.83 & 0.0020 \\
\hline Garden & 7.04 & $<0.001$ & 6.49 & 0.0023 & 6.16 & 0.0038 & 6.02 & 0.0047 \\
\hline Pool & 24.39 & $<0.001$ & 23.99 & $<0.001$ & 23.70 & $<0.001$ & 22.75 & $<0.001$ \\
\hline $\begin{array}{l}\text { Population } \\
\text { density }\end{array}$ & $n a$ & $n a$ & -1.48 & 0.0454 & $n a$ & $n a$ & $n a$ & $n a$ \\
\hline $\begin{array}{l}\text { Built-up } \\
\text { density }\end{array}$ & $n a$ & $n a$ & $n a$ & $n a$ & -2.50 & 0.0015 & -2.31 & 0.0056 \\
\hline Adjusted $\mathrm{R}^{2}$ & \multicolumn{2}{|c|}{0.4039} & \multicolumn{2}{|c|}{0.4050} & \multicolumn{2}{|c|}{0.4073} & \multicolumn{2}{|c|}{$0.4162^{\dagger}$} \\
\hline
\end{tabular}

332 Note. $\dagger$ : likelihood-ratio based pseudo-R-Squared calculated using package 'MuMIn' (Barton,

333 2020), na: not applicable 
334 The final baseline model contains linear effects of the number of adults (centered at 1), the number of children, categorized income per equivalent adult, rainwater use, scaled total living

336 area in square meters, and the presence of (a) bathtub(s), garden(s), and permanent pool(s)

337 (Figure 5). "Average" was set as the reference level of income per equivalent adult, while the

338 reference level of rainwater use is "no use". None of the interactions or quadratic terms of 339 independent variables significantly improves the predictive power of the model. Variables that 340 were not included in the final models (due to having a low-significant level or leading to models 341 with higher MSPE) are not reported in this figure but will be discussed further later.

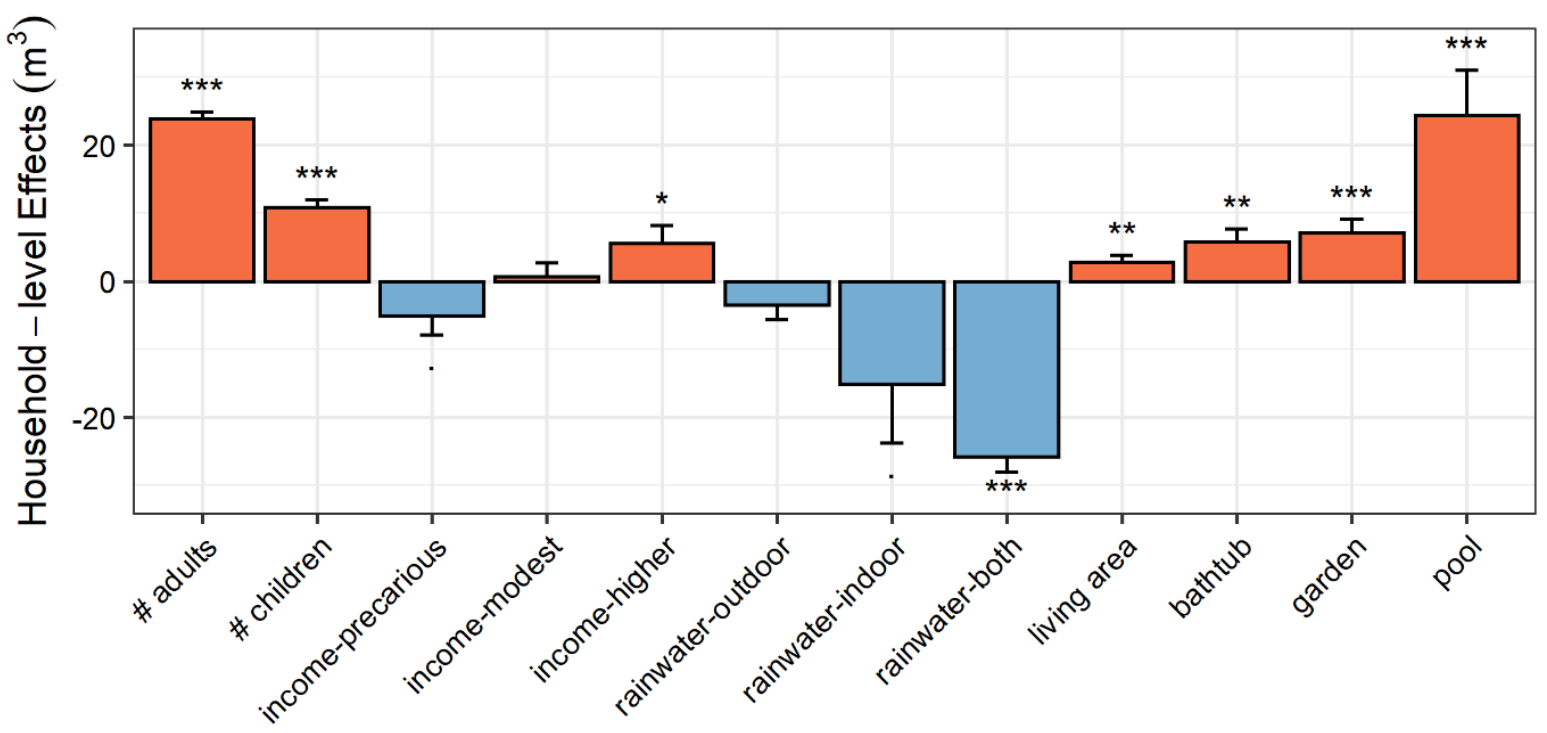

343 Figure 5. Estimated effects of predictors on total household water use, their standard deviation, 344 and their significant level (p-value $\left.<0.05:^{*},<0.01:^{* *},<0.001: * * *\right)$ for the baseline model

345 When a group of variables is last added to the model, changes in R-square represent the unique variance which that particular group explains above and beyond the other variables in the model. Hence, it can be used to compare the importance of different predictor groups in the

348 final models. Sociodemographic factors (household size and income) are the most prominent

349 since it increases the R-square by 0.2737 ; the alternative source of water and dwelling 350 properties only raise the R-square by 0.0534 and 0.0212 , respectively (Table 3 ). 
351 Table 3. Added explained variation by each group of predictors when it was added last

\begin{tabular}{|l|l|l|l|l|}
\hline Variable & Socio-demographics & Rainwater use & $\begin{array}{l}\text { Dwelling } \\
\text { characteristics }\end{array}$ & Spatial factors \\
\hline Increase $\mathrm{R}^{2}$ & 0.2737 & 0.0534 & 0.0212 & $0.0010-0.0123$ \\
\hline
\end{tabular}

\section{$352 \quad 3.2 .1 \quad$ Household characteristics}

353 Household composition is the most important explanatory variable in our model since it

354 improves the percentage of explained variance by nearly $27 \%$, while effects for all other

355 important variables are controlled. Although the quadratic effects of the number of adults and

356 the number of children are not statistically significant, the economies of scale in water use are

357 still observed in the dataset. While single-member families consumed, on average, $40 \mathrm{~m}^{3} /$ year,

358 the estimated increase in water use for every additional adult is $24 \mathrm{~m}^{3}$. The estimated value for

359 each added child is even lower $\left(11 \mathrm{~m}^{3}\right)$. The calculated equivalence scales for water

360 consumption using this data are 0.6 and 0.3 , respectively, for each additional adult and child.

361 These values are close to the OECD-modified equivalence scales of needs which are 0.5 to

362 each additional adult member and 0.3 to each child (OECD, 2011). Hence, it is advisable for

363 water use per capita to be calculated using equivalence scales rather than the total number of

364 inhabitants as is common practice (Billings and Jones, 2008).

365 The positive effect of income was widely accepted and empirically demonstrated in the

366 literature (Corbella and Pujol, 2009; Kenney et al., 2008). A statistically significant effect of

367 income was also found in this study. Higher-income families consume on average 5-6 $\mathrm{m}^{3} \mathrm{a}$

368 year more than the average families, while precarious families consume $4-5 \mathrm{~m}^{3}$ less. Water

369 demand literature often explained the effect of income on the quantity of water consumption

370 by the direct upsurge caused by lifestyle or indirect increase through having dishwashers,

371 gardens, or pools (Schleich and Hillenbrand, 2009). Since the effects of water use equipment 
were not significant and the effects of dwelling characteristics and rainwater use were controlled (and discussed below), the effect of income in this analysis may solely be explained by the household's capacity to buy more water, which can be traced to habit and living standards.

376 Information of reference people such as gender, job, and educational level are all not

377 statistically significant. Jorgensen et al. (2014) have argued that while individual factors such as job and educational level influence water use of single-member households, these variables do not necessarily represent the characteristics of the whole family in larger households.

\subsubsection{Alternative water sources}

381 In this study, drinking, making meals, dishwashing, personal hygiene, clothes washing, house cleaning, and toilet flushing were considered indoor purposes; garden irrigation, car washing, external cleaning, and permanent or inflatable pool filling were treated as outdoor use. Figure 5 shows a substantial decrease in piped water demand for families using rainwater for indoor purposes (for indoor-only as well as both indoor and outdoor). Since indoor purposes such as laundry and toilet flushing account for more than half of household total water use in Western

387 Europe (Lallana et al., 2001; Pakula and Stamminger, 2015), it is logical that less piped water is saved when rainwater is only used outdoor. Even though the effect of rainwater on distribution water demand is promising, further studies should be considered. Neither the actual

390 amount of rainwater used by the households nor potential rebound effects could be assessed in 391 this study.

\subsubsection{Dwelling properties}

393 Dwelling characteristics (e.g., year built, total living area, and the number of rooms) are often

394 considered important factors in water demand literature (Fox et al., 2009; Wentz and Gober, 
395 2007). Besides having strong predictive power, this information is often the only available data 396 for newly developed unoccupied housing areas. One concern in including both household size

397 and living area is their natural correlation. The VIFs of the final models did not signal any 398 problem with multicollinearity, even though a significant positive Pearson correlation of 0.233 399 was observed.

400 When controlling for other factors, a significant but marginal effect of the total living area was 401 found. It can be interpreted as the average increase in water use with every additional unit of 402 living area when keeping other factors such as household size unchanged. The presences of (a) 403 bathtub(s), garden(s), and pool(s) also induce a significant increase in water consumption. It is 404 an expected result since there has been an amount of supporting evidence in the literature (Fox 405 et al., 2009; Wentz and Gober, 2007). Although previous studies have suggested the seasonal 406 pattern in water use for gardening and pool filling (Corbella and Pujol, 2009), it was not 407 possible to address this fluctuation in our study since household water consumption in Wallonia 408 is habitually recorded and billed once per year.

409 The non-significant effects of dwelling type and year built contradict findings in the literature 410 (Fox et al., 2009; Stoker and Rothfeder, 2014). House-Peters et al. (2010) have successfully 411 linked higher water consumption with newer properties. Their explanation for this effect is that 412 new houses are often bigger and have higher values. However, Harlan et al. (2009) expected 413 that newer homes would consume less water due to the higher presence of rainwater tanks or 414 water-efficient equipment. In Wallonia, around $60 \%$ of houses built after 1990 have rainwater $415 \operatorname{tank}(\mathrm{s})$ for domestic use while that number for older homes is less than $40 \%$. However, since 416 household income, living area, presence of (a) pool(s), and rainwater use have been controlled 417 in our models, the unique parts of the year-built and house type effects become trivial. 


\subsubsection{Water appliance and people attitudes}

419 Water appliance ownerships and people's opinions regarding water quality were found to be 420 not significant in explaining household water use in this data. Lack of details and variations in 421 these variables might be the primary explanation. Previous studies often emphasized the role 422 of behaviors in influencing water use/saving devices' effects. For example, when people know 423 that their showerhead is low-flow, they tend to take longer showers (Campbell et al., 2004).

424 The study of Richter (2010) also suggested that the amount of water consumed for dishwashing 425 depends more on people's habits (e.g., pre-rinsing the dishes, program selection) than the mere 426 presence of a dishwasher. Since actual water use habits were not asked in the Utility Survey, 427 other studies are needed to deepen the knowledge of people's customs in Wallonia and their 428 effects on total water demand.

\subsection{Spatial variation in residential water consumption}

430 Since Moran's I statistic suggests spatial autocorrelation in household water consumption, two approaches discussed in 2.3 were employed to model the spatial effects on water use. Moran's I test $(p$-value $=0.9509)$ for error terms of the most complicated final model (i.e., the model with both random intercepts at the municipality level and building density at the statistical unit level) suggests that the model has well captured the spatial variation in the data. Detailed results of these models are discussed below.

436 Although boxplots in Figure 3 show lower water demand in both high-density urban areas and

437 low-density rural areas than average-density peri-urban areas, both quadric terms of population 438 and building densities did not prove to be necessary. The population density estimate suggests 439 a decrease of $-1.48 \mathrm{~m}^{3}(\mathrm{p}$-value $=0.0454)$ in average annual household consumption when 440 population density increase by one standard deviation (Table 2). The negative effect of building 441 density $\left(-2.50 \mathrm{~m}^{3}\right)$ has a higher significant level (p-value $\left.=0.0015\right)$. Since the registered 
442 population used for population density calculation might differ from the actual residential 443 population, building density might be a better indicator of urban form, thus explaining water 444 use slightly better. In contrast to March and Saurí (2010), who found urban density is the most 445 critical variable to explain water consumption, the effects of density in this study, though 446 significant, hardly improve the adjusted R-square of the model (Table 2). Previous studies often 447 found that higher urban density reduces water demand mainly through smaller lot sizes (Fox et 448 al., 2009; Villar-Navascués and Pérez-Morales, 2018). Even though lot size was not available 449 in this study, after controlling for similar factors such as living area and the presence of (a) 450 pool(s) or garden(s), the remaining effect of densities becomes marginal.

451 Additionally, to accommodate the potential unobserved effects of other municipality 452 characteristics besides density, random intercepts at the municipality level were introduced into the model. It also allowed to separately estimate the within and between municipality variations of household water use. Although the significant random effects of municipalities (p-value = 0.0354) implied an unexplained spatial heterogeneity in average water consumption, based on

456 R-square values in Table 2, its contribution to model improvement is much less than those of 457 household-level factors, as discussed in section 3.2.

458 Even though both fixed effects of densities and random effects of municipalities are significant, all models with spatial factors showed limited improvements compared to the baseline model (Table 2). A potential explanation for this phenomenon is that the spatial variation in water 461 consumption has already partly been explained by other predictors in the baseline model, 462 especially since most of them also express spatial heterogeneity (see section 3.1). In other 463 words, families living in the same area often share similar characteristics in socio-economic 464 status, water use habits, and the presence of water use facilities - thus consume a comparable amount of water. 


\section{Conclusions}

467 By combining the data from the Utility Survey and historical water consumption, this study 468 has addressed the effects of (1) household characteristics, (2) alternative sources of water, (3)

469 dwelling properties, (4) water appliances, (5) attitudes, and (6) urban form on household water 470 uses in Wallonia. Since this is a cross-sectional study, time-varying variables such as prices, weather, or the general trend in water demand could not be studied.

472 The result has confirmed the importance of household size in explaining single-family water use from previous studies. Data from Wallonia suggests an equivalence scale of water use with

474 a value of 1 for the first adult, 0.6 for every additional adult member, and 0.3 for any added child. From the demand point of view, the result from this study also supports a substantial saving $(20 \%-35 \%)$ in piped water consumption when rainwater is used as an alternative source, especially for indoor purposes. However, from a financial perspective, it might reduce even more water utilities' revenue and lead to difficulties in service operation and new energyefficient systems investment. The general belief that the amount of household water use 480 depends partly on where they live seems to be explained solely by the fact that households in the same area often share similar characteristics such as household composition, income, lot area, the practice of using rainwater, and having (a) garden(s) or pool(s). After controlling for these factors, the spatial effect on water consumption becomes almost negligible.

Besides contributing to the understanding of household water use determinants, this study also suggests further consideration of several current water policies. Since the effect of household location is almost negligible after controlling for household characteristics, policymaking could occur at a regional scale, particularly for territories with uneven water availability, such as Wallonia. Additionally, the effect of household income is modest, especially compared to household size, which calls into question the ability to meet the equity objective of progressive 
490 tariffs based on water consumption at the connection level. As previous studies have 491 recognized (Donkor, 2010; Whittington and Nauges, 2020), without considering household 492 size, poorer households with more members often faced higher average water prices when 493 increasing-block tariffs are applied.

\section{Acknowledgments}

495 This work has been funded through the Wal-e-Cities Project, supported by the European 496 Regional Development Fund (ERDF) and the Walloon Region. We are also grateful to 497 anonymous reviewers and Professor Janice A. Beecher for their valuable comments and 498 suggestions. The authors declare no conflict of interest.

\section{Data statement}

500 The statistical unit and population data used in this study can be obtained via the websites of 501 the Belgian Statistical Office (https://statbel.fgov.be/en/open-data?category=209) and Federal 502 Public Service Finance (https://finances.belgium.be/fr/particuliers/habitation/cadastre/plan503 cadastral/lambert-72). The survey and water consumption data were kindly provided by

504 Aquawal and CEHD under the approval of the Service Public de Wallonie via confidential 505 agreements and thus are not accessible to the public or research community. Interested parties 506 may directly contact Aquawal (www.aquawal.be) and CEHD (https://www.cehd.be/) to 507 request the data.

\section{Appendix A: Water tariff in Wallonia}

509 Following the European principles of full cost recovery, a single water tariff structure covering

510 both the cost of water production (CVD) and wastewater treatment (CVA) is imposed for all

511 families in Wallonia. The final bill contains a fixed subscription fee, a three-block volumetric

512 charge, and a contribution to social fund following the formulas in Table A1. 
513 Table A1. Water tariff structure in Wallonia

\begin{tabular}{|c|c|}
\hline Tariff parts & Formula \\
\hline Fixed subscription fee & $20 * \mathrm{CVD}+30 * \mathrm{CVA}$ (per household) \\
\hline \multicolumn{2}{|l|}{ Volumetric charge } \\
\hline From 0 to $30 \mathrm{~m}^{3}$ & $0.5^{*} \operatorname{CVD}\left(\right.$ per $\left.\mathrm{m}^{3}\right)$ \\
\hline From 30 to $500 \mathrm{~m}^{3}$ & CVD + CVA $\left(\right.$ per $\left.\mathrm{m}^{3}\right)$ \\
\hline Above $500 \mathrm{~m}^{3}$ & $0.9 * \mathrm{CVD}+\mathrm{CVA}\left(\right.$ per $\left.\mathrm{m}^{3}\right)$ \\
\hline Social Water Fund contribution & $0.0125 €\left(\right.$ per m$\left.^{3}\right)$ \\
\hline Value-added tax & $6 \%$ of the total bill \\
\hline
\end{tabular}

514 The CVD is recalculated each year by water companies following a standardized accounting

515 plan set by the Walloon government. Any increase in CVD requires opinions from Water

516 Control Committee and approval from the Federal Public Service Economy. On the other hand,

517 a single CVA is set for the whole Walloon region by the Société Publique de Gestion de l'Eau

518 (SPGE) each year. Figure A1 presents the recent evolution in CVA and CVDs of the four

519 primary distributers. The total bills calculated for families consuming at an average level of

$52070 \mathrm{~m}^{3} /$ year showed a constant increase of about $5 \%$ each year (Figure A1).
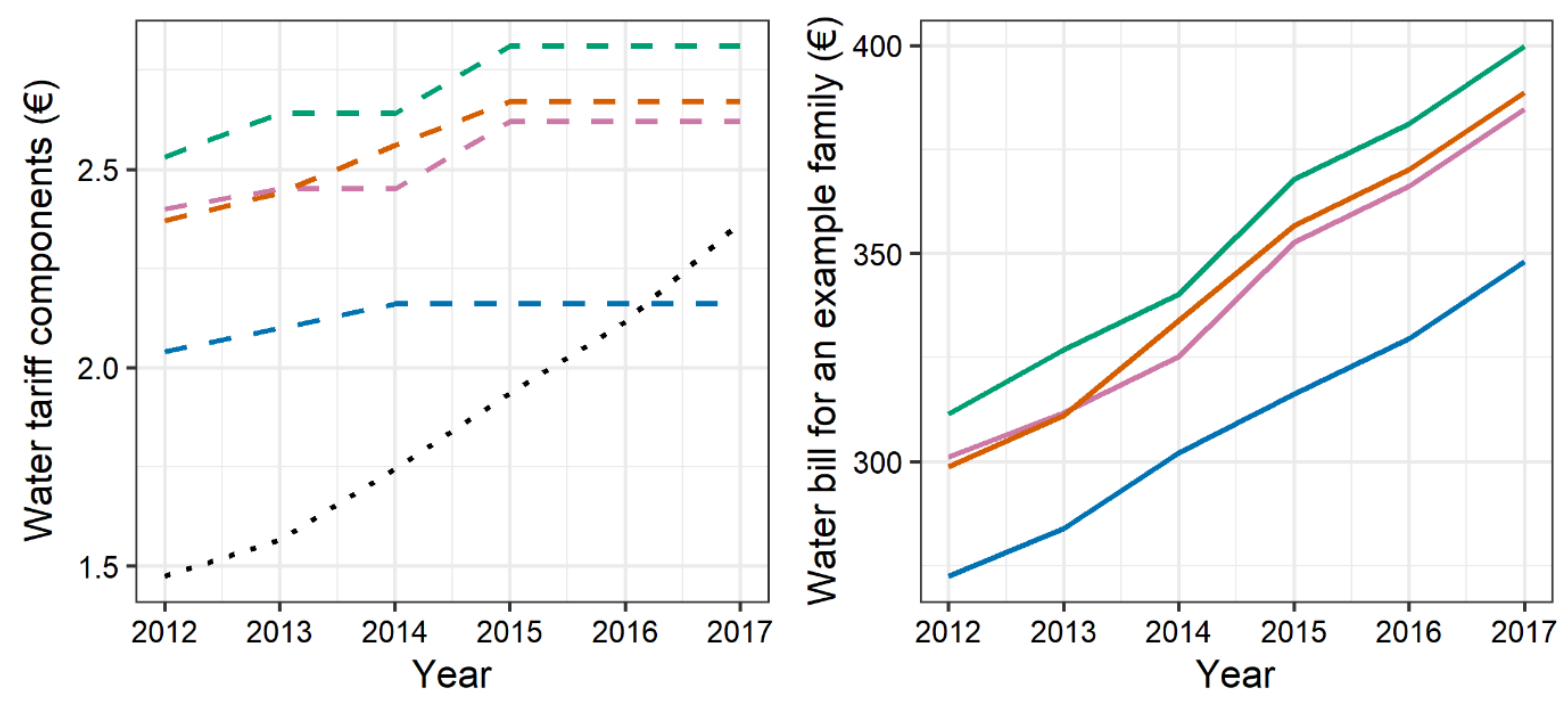
522 Figure A1. A plot of increasing CVD and CVA in recent years (Left) and a plot of example

523 annual water bills for an average family who consumes $70 \mathrm{~m}^{3} /$ year (Right).

\section{Appendix B: Variables' summary statistics}

525 Table B1. Summary statistics of all numerical factors

\begin{tabular}{|l|l|l|l|l|l|l|}
\hline Variable & Unit & Mean & SD & Min & Max & Missing \\
\hline Verified consumption & $\mathrm{m}^{3} /$ year & 69.31 & 44.39 & 0 & 523.95 & 156 \\
\hline $\begin{array}{l}\text { Consumption per capita per } \\
\text { day }\end{array}$ & L/p/d & 85.20 & 50.80 & 0 & 717.74 & 287 \\
\hline Water bill 2014 & $€$ & 347.96 & 207.38 & 110.55 & $2,445.09$ & 20 \\
\hline Number of adults & & 2.06 & 0.92 & 0 & 3 & 141 \\
\hline Number of children & & 0.35 & 0.77 & 0 & 4 & 141 \\
\hline Household size & & 2.4 & 1.32 & 1 & 9 & 141 \\
\hline Reference person's age & & 52.15 & 16.35 & 19 & 95 & 141 \\
\hline Household income & $€ /$ month & 2,461 & 1,191 & 125 & 5,250 & 109 \\
\hline Income per equivalent adult & $€ /$ year & 18,613 & 7,624 & 750 & 57,000 & 254 \\
\hline Water affordability & $\%$ & 1.40 & 1.04 & 0.21 & 13.10 & 124 \\
\hline Total living area & $\mathrm{m}^{2}$ & 128.22 & 58.52 & 20 & 400 & 22 \\
\hline
\end{tabular}

526 Table B2. Summary statistics of all categorical factors

\begin{tabular}{|c|c|c|c|}
\hline Variable & Levels & Count & Percentage \\
\hline \multirow[t]{4}{*}{ Using water from private well } & no & 2018 & 95.23 \\
\hline & outdoor-only & 40 & 1.89 \\
\hline & indoor-only & 6 & 0.28 \\
\hline & both & 55 & 2.60 \\
\hline \multirow[t]{4}{*}{ Using rainwater } & no & 1111 & 52.43 \\
\hline & outdoor-only & 465 & 21.94 \\
\hline & indoor-only & 24 & 1.13 \\
\hline & both & 519 & 24.49 \\
\hline \multirow[t]{6}{*}{ Province } & Walloon Brabant & 278 & 13.12 \\
\hline & Hainaut & 738 & 34.83 \\
\hline & Liège & 603 & 28.46 \\
\hline & Luxembourg & 114 & 5.38 \\
\hline & Namur & 246 & 11.61 \\
\hline & missing & 140 & 6.61 \\
\hline \multirow[t]{5}{*}{ Distributor } & AIEM & 1 & 0.05 \\
\hline & CILE & 329 & 15.53 \\
\hline & IECBW & 169 & 7.98 \\
\hline & INASEP & 44 & 2.08 \\
\hline & SWDE & 1558 & 73.53 \\
\hline
\end{tabular}




\begin{tabular}{|c|c|c|c|}
\hline & Communal organizations & 9 & 0.42 \\
\hline & missing & 9 & 0.42 \\
\hline \multirow[t]{3}{*}{ Reference person gender } & Female & 581 & 27.42 \\
\hline & Male & 1369 & 64.61 \\
\hline & missing & 169 & 7.98 \\
\hline \multirow[t]{13}{*}{ Reference person job } & (pre)retired & 814 & 38.41 \\
\hline & freelancer & 25 & 1.18 \\
\hline & housewife/husband & 27 & 1.27 \\
\hline & incapable & 64 & 3.02 \\
\hline & independent & 75 & 3.54 \\
\hline & manager & 88 & 4.15 \\
\hline & other & 39 & 1.84 \\
\hline & private sector & 278 & 13.12 \\
\hline & state employee & 282 & 13.31 \\
\hline & student & 8 & 0.38 \\
\hline & unemployed & 75 & 3.54 \\
\hline & worker & 167 & 7.88 \\
\hline & missing & 177 & 8.35 \\
\hline \multirow[t]{7}{*}{ Reference person educational level } & before high-school & 268 & 12.65 \\
\hline & high-school & 326 & 15.38 \\
\hline & professional & 158 & 7.46 \\
\hline & technique & 203 & 9.58 \\
\hline & higher not university & 564 & 26.62 \\
\hline & university & 323 & 15.24 \\
\hline & missing & 277 & 13.07 \\
\hline $\begin{array}{l}\text { Receive help from the Social Water } \\
\text { Fund }\end{array}$ & yes & 4 & 0.19 \\
\hline $\begin{array}{l}\text { Financially difficult for water } \\
\text { paying }\end{array}$ & yes & 143 & 6.75 \\
\hline \multirow[t]{5}{*}{ Housing tenure } & owner - mortgage loan & 729 & 34.40 \\
\hline & owner & 1029 & 48.56 \\
\hline & renter - private sector & 224 & 10.57 \\
\hline & renter - social or public & 101 & 4.77 \\
\hline & missing & 36 & 1.70 \\
\hline \multirow[t]{5}{*}{ Dwelling type } & 4 facades & 964 & 45.49 \\
\hline & 3 facades & 434 & 20.48 \\
\hline & 2 facades & 541 & 25.53 \\
\hline & apartment/studio & 172 & 8.12 \\
\hline & missing & 8 & 0.38 \\
\hline \multirow[t]{6}{*}{ Year built } & Before 1945 & 743 & 35.06 \\
\hline & $1946-1970$ & 479 & 22.61 \\
\hline & $1971-1990$ & 486 & 22.94 \\
\hline & $1991-2000$ & 161 & 7.60 \\
\hline & 2001 and after & 244 & 11.51 \\
\hline & missing & 6 & 0.28 \\
\hline
\end{tabular}




\begin{tabular}{|c|c|c|c|}
\hline \multirow[t]{5}{*}{ Number of kitchens } & 0 & 19 & 0.90 \\
\hline & 1 & 2063 & 97.36 \\
\hline & 2 & 30 & 1.42 \\
\hline & 3 or more & 4 & 0.19 \\
\hline & missing & 3 & 0.14 \\
\hline \multirow[t]{5}{*}{ Number of living rooms } & 0 & 24 & 1.13 \\
\hline & 1 & 1817 & 85.75 \\
\hline & 2 & 246 & 11.61 \\
\hline & 3 or more & 29 & 1.37 \\
\hline & missing & 3 & 0.14 \\
\hline \multirow[t]{5}{*}{ Number of bedrooms } & 0 & 33 & 1.56 \\
\hline & 1 & 227 & 10.71 \\
\hline & 2 & 573 & 27.04 \\
\hline & 3 or more & 1281 & 60.45 \\
\hline & missing & 5 & 0.24 \\
\hline \multirow[t]{5}{*}{ Number of bathrooms } & 0 & 31 & 1.46 \\
\hline & 1 & 1741 & 82.16 \\
\hline & 2 & 309 & 14.58 \\
\hline & 3 or more & 35 & 1.65 \\
\hline & missing & 3 & 0.14 \\
\hline \multirow[t]{5}{*}{ Number of toilets } & 0 & 79 & 3.73 \\
\hline & 1 & 1202 & 56.72 \\
\hline & 2 & 720 & 33.98 \\
\hline & 3 or more & 115 & 5.43 \\
\hline & missing & 3 & 0.14 \\
\hline $\begin{array}{l}\text { Using distribution water for pool } \\
\text { filling }\end{array}$ & yes & 149 & 7.03 \\
\hline Presence of permanent pool & yes & 46 & 2.17 \\
\hline $\begin{array}{l}\text { Recent replacement of permanent } \\
\text { pool }\end{array}$ & yes & 14 & 0.66 \\
\hline Presence of inflatable pool & yes & 113 & 5.33 \\
\hline $\begin{array}{l}\text { Recent replacement of inflatable } \\
\text { pool }\end{array}$ & yes & 37 & 1.75 \\
\hline $\begin{array}{l}\text { Using distribution water for garden } \\
\text { irrigation }\end{array}$ & yes & 1615 & 76.22 \\
\hline Presence of dishwasher & yes & 1413 & 66.68 \\
\hline Recent replacement of dishwasher & yes & 605 & 28.55 \\
\hline Presence of washing machine & yes & 1950 & 92.02 \\
\hline $\begin{array}{l}\text { Recent replacement of washing } \\
\text { machine }\end{array}$ & yes & 776 & 36.62 \\
\hline Presence of rainwater tank & yes & 849 & 40.07 \\
\hline $\begin{array}{l}\text { Recent replacement of rainwater } \\
\text { tank }\end{array}$ & yes & 86 & 4.06 \\
\hline \multirow[t]{4}{*}{ Presence of bathtub or shower } & none & 176 & 8.31 \\
\hline & shower & 387 & 18.26 \\
\hline & bathtub & 845 & 39.88 \\
\hline & both & 711 & 33.55 \\
\hline
\end{tabular}




\begin{tabular}{|l|l|l|l|}
\hline Presence of efficient showerhead & yes & 830 & 39.17 \\
\hline $\begin{array}{l}\text { Recent replacement of efficient } \\
\text { showerhead }\end{array}$ & yes & 394 & 18.59 \\
\hline Presence of efficient toilet & yes & 1533 & 72.35 \\
\hline $\begin{array}{l}\text { Recent replacement of efficient } \\
\text { toilet }\end{array}$ & yes & 511 & 24.12 \\
\hline Presence of dried toilet & yes & 27 & 1.27 \\
\hline Recent replacement of dried toilet & yes & 16 & 0.76 \\
\hline $\begin{array}{l}\text { Government subsidies for rainwater } \\
\text { tank }\end{array}$ & yes & 5 & 0.24 \\
\hline Confidence in piped water quality & confident & 1055 & 49.79 \\
\hline & rather confident & 591 & 27.89 \\
\hline & neither confident nor suspicious & 240 & 11.33 \\
\hline & rather suspicious & 96 & 4.53 \\
\hline & suspicious & 50 & 2.36 \\
\hline & no opinion & 67 & 3.16 \\
\hline & missing & 20 & 0.94 \\
\hline Pay per volume use & yes & 2088 & 98.54 \\
\hline & missing & 1 & 0.05 \\
\hline Budget water meter & yes & 3 & 0.14 \\
\hline Limited water meter & yes & 1 & 0.05 \\
\hline
\end{tabular}

\section{References}

Anfrie, M., Cassilde, S., Gobert, O., Kryvobokov, M., Pradella, S., 2017. Chiffres clés du logement en Wallonie https://www.cehd.be/media/1160/2018_05_03_chiffrescles2017_final.pdf

Aquawal, 2017. Statistiques 2017 de l'eau potable et de l'assainissement des eaux usees en Wallonie. $\quad \mathrm{https}: / / \mathrm{www}$.aquawal.be/servlet/Repository/rapport-statistiques2017.pdf?ID=16387

Aquawal, CEHD, 2015. Étude sur les consommations résidentielles d'eau et d'énergie en Wallonie. https://cehd.be/media/1151/rapport-final-aquawal-cehd-v8.pdf

Ayinde, K., Lukman, A.F., Arowolo, O., 2015. Robust regression diagnostics of influential observations in linear regression model. Open J. Stat. 05, 273-283. https://doi.org/10.4236/ojs.2015.54029

Barton, K., 2020. MuMIn: Multi-Model Inference. R package version 1.43.17. https://cran.rproject.org $/$ package $=$ MuMIn

Basani, M., Isham, J., Reilly, B., 2008. The determinants of water connection and water consumption: empirical evidence from a Cambodian household survey. World Dev. 36, 953-968. https://doi.org/10.1016/j.worlddev.2007.04.021

Bates, D., Mächler, M., Bolker, B.M., Walker, S.C., 2015. Fitting linear mixed-effects models using lme4. J. Stat. Softw. 67, 74. https://doi.org/10.18637/jss.v067.i01

Beecher, J.A., Chesnutt, T.W., 2012. Declining water sales and utility revenues: Solutions for conservation? A White Pap. Natl. Water Rates Summit. https://www.allianceforwaterefficiency.org/sites/www.allianceforwaterefficiency.org/fil es/highlight_documents/Summit-Summary-and-Declining-Water-Sales-and-UtilityRevenues-2012-12-16.pdf

Bich-Ngoc, N., Teller, J., 2020. Potential effects of the COVID-19 pandemic through changes 
in outbound tourism on water demand: The case of Liège (Belgium). Water (Switzerland) 12, 2820. https://doi.org/10.3390/w12102820

Bich-Ngoc, N., Teller, J., 2018. A review of residential water consumption determinants, in: Lecture Notes in Computer Science (Including Subseries Lecture Notes in Artificial Intelligence and Lecture Notes in Bioinformatics). Springer, pp. 685-696. https://doi.org/10.1007/978-3-319-95174-4_52

Billings, R.B., Jones, C. V., 2008. Simple forecasting methods and reality checks, in: Forecasting Urban Water Demand. American Water Works Association, pp. 59-82.

Buras, A., Rammig, A., S. Zang, C., 2020. Quantifying impacts of the 2018 drought on European ecosystems in comparison to 2003. Biogeosciences 17, 1655-1672. https://doi.org/10.5194/bg-17-1655-2020

Campbell, H.E., Johnson, R.M., Larson, E.H., 2004. Prices, devices, people, or rules: the relative effectiveness of policy instruments in water conservation. Rev. Policy Res. 21, 637-662. https://doi.org/10.1111/j.1541-1338.2004.00099.x

Corbella, H.M., Pujol, D.S., 2009. What lies behind domestic water use? A review essay on the drivers of domestic water consumption. Bol. la AGE 297-314. https://core.ac.uk/download/pdf/13269359.pdf

Donkor, E.A., 2010. Evaluating increasing block tariff pricing policies when applied to multiple household connections 8060. https://doi.org/10.1080/02508060.2010.533346

Donkor, E.A., Mazzuchi, T.A., Soyer, R., Alan Roberson, J., 2014. Urban water demand forecasting: Review of methods and models. J. Water Resour. Plan. Manag. 140, 146159. https://doi.org/10.1061/(ASCE)WR.1943-5452.0000314

Duerr, I., Merrill, H.R., Wang, C., Bai, R., Boyer, M., Dukes, M.D., Bliznyuk, N., 2018. Forecasting urban household water demand with statistical and machine learning methods using large space-time data: A comparative study. Environ. Model. Softw. 102, 29-38. https://doi.org/10.1016/j.envsoft.2018.01.002

EurEau, 2017. Europe's water in figures - An overview of the European drinking water and waste water sectors. https://www.danva.dk/media/3645/eureau_water_in_figures.pdf

European Environment Agency, 2019. Use of freshwater resources in Europe. https://www.eea.europa.eu/data-and-maps/indicators/use-of-freshwater-resources3/assessment-4

Fox, C., McIntosh, B.S., Jeffrey, P., 2009. Classifying households for water demand forecasting using physical property characteristics. Land use policy 26, 558-568. https://doi.org/10.1016/j.landusepol.2008.08.004

Franczyk, J., Chang, H., 2009. Spatial analysis of water use in Oregon, USA, 1985-2005. Water Resour. Manag. 23, 755-774. https://doi.org/10.1007/s11269-008-9298-9

Gato, S., Jayasuriya, N., Roberts, P., 2007. Temperature and rainfall thresholds for base use urban water demand modelling. J. Hydrol. 337, 364-376. https://doi.org/10.1016/j.jhydrol.2007.02.014

Ghavidelfar, S., Shamseldin, A.Y., Melville, B.W., 2017. Future implications of urban intensification on residential water demand. J. Environ. Plan. Manag. 60, 1809-1824. https://doi.org/10.1080/09640568.2016.1257976

Harlan, S.L., Yabiku, S.T., Larsen, L., Brazel, A.J., 2009. Household water consumption in an arid city: Affluence, affordance, and attitudes. Soc. Nat. Resour. 22, 691-709. https://doi.org/10.1080/08941920802064679

House-Peters, L., Pratt, B., Chang, H., 2010. Effects of urban spatial structure, sociodemographics, and climate on residential water consumption in Hillsboro, Oregon. J. Am. Water Resour. Assoc. 46, 461-472. https://doi.org/10.1111/j.17521688.2009.00415.x

House-Peters, L.A., Chang, H., 2011. Urban water demand modeling: Review of concepts, 
methods, and organizing principles. Water Resour. Res. 47. https://doi.org/10.1029/2010WR009624

Jorgensen, B.S., Martin, J.F., Pearce, M.W., Willis, E.M., 2014. Predicting household water consumption with individual-level variables. Environ. Behav. 46, 872-897. https://doi.org/10.1177/0013916513482462

Kenney, D.S., Goemans, C., Klein, R., Lowrey, J., Reidy, K., 2008. Residential water demand management: Lessons from Aurora, Colorado. J. Am. Water Resour. Assoc. 44, 192-207. https://doi.org/10.1111/j.1752-1688.2007.00147.x

Kontokosta, C.E., Jain, R.K., 2015. Modeling the determinants of large-scale building water use: Implications for data-driven urban sustainability policy. Sustain. Cities Soc. 18, 4455. https://doi.org/10.1016/j.scs.2015.05.007

Kulinkina, A. V., Kosinski, K.C., Liss, A., Adjei, M.N., Ayamgah, G.A., Webb, P., Gute, D.M., Plummer, J.D., Naumova, E.N., 2016. Piped water consumption in Ghana: a case study of temporal and spatial patterns of clean water demand relative to alternative water sources in rural small towns. Sci. Total Environ. 559, 291-301. https://doi.org/10.1016/j.scitotenv.2016.03.148

Kuznetsova, A., Brockhoff, P.B., Christensen, R.H.B., 2017. lmerTest package: Tests in linear mixed effects models. J. Stat. Softw. 82, 1-26. https://doi.org/10.18637/jss.v082.i13

Lallana, C., Krinner, W., Estrela, T., Nixon, S., Leonard, J., Berland, J.M., 2001. Sustainable water use in Europe - Part 2: Demand management, European Environment Agency. https://www.eea.europa.eu/publications/Environmental_Issues_No_19

Maidment, D.R., Miaou, S. -P, Crawford, M.M., 1985. Transfer function models of daily urban water use. Water Resour. Res. 21, 425-432. https://doi.org/10.1029/WR021i004p00425

March, H., Saurí, D., 2010. The suburbanization of water scarcity in the Barcelona metropolitan region: Sociodemographic and urban changes influencing domestic water consumption. Prof. Geogr. 62, 32-45. https://doi.org/10.1080/00330120903375860

Marzano, R., Rougé, C., Garrone, P., Grilli, L., Harou, J.J., Pulido-Velazquez, M., 2018. Determinants of the price response to residential water tariffs: Meta-analysis and beyond. Environ. Model. Softw. 101, 236-248. https://doi.org/10.1016/j.envsoft.2017.12.017

Mini, C., Hogue, T.S., Pincetl, S., 2015. The effectiveness of water conservation measures on summer residential water use in Los Angeles, California. Resour. Conserv. Recycl. 94, 136-145. https://doi.org/10.1016/j.resconrec.2014.10.005

Nauges, C., Whittington, D., 2009. Estimation of water demand in developing countries: an overview. World Bank Res. Obs. 25, 263-294. https://doi.org/10.1093/wbro/lkp016

OECD, 2011. What are equivalence scales? http://www.oecd.org/els/soc/OECD-NoteEquivalenceScales.pdf

Pakula, C., Stamminger, R., 2015. Energy and water savings potential in automatic laundry washing processes. Energy Effic. 8, 205-222. https://doi.org/10.1007/s12053-014-92880

Pakula, C., Stamminger, R., 2010. Electricity and water consumption for laundry washing by washing machine worldwide. Energy Effic. 3, 365-382. https://doi.org/10.1007/s12053009-9072-8

Pint, E.M., 1999. Household responses to increased water rates during the California drought. Land Econ. 75, 246-266. https://doi.org/10.2307/3147009

Polebitski, A.S., Palmer, R.N., 2010. Seasonal residential water demand forecasting for census tracts. J. Water Resour. Plan. Manag. 136, 27-36. https://doi.org/10.1061/ASCEWR.1943-5452.0000003

Polebitski, A.S., Palmer, R.N., Waddell, P., 2011. Evaluating water demands under climate change and transitions in the urban environment. J. Water Resour. Plan. Manag. 137, 249257. https://doi.org/10.1061/(ASCE)WR.1943-5452.0000112 
652

653

654

655

656

657

658

659

660

661

662

663

664

665

666

667

668

669

670

671

672

673

674

675

676

677

678

679

680

681

682

683

R Core Team, 2020. R: A language and environment for statistical computing. https://www.rproject.org/

Richter, C.P., 2010. Automatic dishwashers: Efficient machines or less efficient consumer habits? Int. J. Consum. Stud. 34, 228-234. https://doi.org/10.1111/j.14706431.2009.00839.x

Richter, C.P., Stamminger, R., 2012. Water consumption in the kitchen - A case study in four European countries. Water Resour. Manag. 26, 1639-1649. https://doi.org/10.1007/s11269-012-9976-5

Schleich, J., Hillenbrand, T., 2009. Determinants of residential water demand in Germany. Ecol. Econ. 68, 1756-1769. https://doi.org/10.1016/j.ecolecon.2008.11.012

Stoker, P., Rothfeder, R., 2014. Drivers of urban water use. Sustain. Cities Soc. 12, 1-8. https://doi.org/10.1016/j.scs.2014.03.002

Vallès-Casas, M., March, H., Saurí, D., 2017. Examining the reduction in potable water consumption by households in Catalonia (Spain): Structural and contingent factors. Appl. Geogr. 87, 234-244. https://doi.org/10.1016/j.apgeog.2017.07.015

Verbeke, G., Molenberghs, G., 2009. Linear mixed models for longitudinal data. Springer Science \& Business Media.

Villar-Navascués, R.A., Pérez-Morales, A., 2018. Factors affecting domestic water consumption on the Spanish Mediterranean coastline. Prof. Geogr. 70, 513-525. https://doi.org/10.1080/00330124.2017.1416302

Wentz, E.A., Gober, P., 2007. Determinants of small-area water consumption for the City of Phoenix, Arizona. Water Resour. Manag. 21, 1849-1863. https://doi.org/10.1007/s11269006-9133-0

Westhoff, M., Dewals, B., 2015. Towards enhanced estimates of future drinking water demand in the Meuse basin, University of Liege. http://hdl.handle.net/2268/172973

Whittington, D., Nauges, C., 2020. An assessment of the widespread use of increasing block tariffs in the municipal water supply sector. Oxford Res. Encycl. Glob. Public Heal. https://doi.org/10.1093/acrefore/9780190632366.013.243

Wong, J.S., Zhang, Q., Chen, Y.D., 2010. Statistical modeling of daily urban water consumption in Hong Kong: Trend, changing patterns, and forecast. Water Resour. Res. 46. https://doi.org/10.1029/2009WR008147 